\title{
European Inflation and Spanish Stock Market
}

Francisco Jareño, Universidad de Castilla-La Mancha, Albacete, Spain

Eliseo Navarro, Universidad de Alcalá, Madrid, Spain

Send correspondence to Francisco Jareño, Departamento de Análisis Económico y Finanzas, Universidad de Castilla-La Mancha, Facultad de CC Económicas y Empresariales, Plaza de la Universidad, 1, 02071 - Albacete (Spain), francisco.jareno@uclm.es (corresponding author), Tel: +34 967599200.

Eliseo Navarro, Departamento de Ciencias Empresariales, Universidad de Alcalá, Facultad de CC Económicas y Empresariales, Plaza de la Victoria, 2, 28802, Alcalá de Henares, Madrid (Spain), eliseo.navarro@uah.es, Tel: +34 918854258. 


\title{
European Inflation and Spanish Stock Market
}

\begin{abstract}
This study examines the short-run response of daily stock prices in the Spanish market to the announcements of inflation news at a sector level at the moments when the Spanish authorities announce the IPC (consumer price index) during the period 1995-2004. The study also incorporates two novel explanatory variables: core inflation and "non-core" inflation rate components on the one hand, and the spread between the Spanish and European inflation rates (harmonized) on the other hand. Conclusions of the study: the "non-core" component of the inflation rate, which is more volatile, has negative effects on some sector returns; additionally, in drawing too far apart from the European inflation rate, the Spanish inflation rate negatively affects sector returns, such as in the "Consumer Goods" sector, which is subject to strong foreign competition. In the long-term analysis, the lagged core inflation (structural component) negatively affects sector returns.
\end{abstract}

Keywords: Inflation announcement; stock return; core inflation; harmonized index of consumer prices (HICP)

JEL Classification: E31, G12, G14, G30, L2 


\section{Introduction}

This article explains the different responses of the stock returns of some economic sectors to inflation announcements by considering two important factors in decisions about economic policy. These two factors should explain, to some extent, the relationship between stock returns and inflation news using event-study methodology.

This study includes two innovative variables: core inflation (measured by the $\mathrm{CPI}$ - consumer price index - removing non-manufactured products and energy) and the spread between the Spanish and European inflation rates (harmonized). The latter grants knowledge of how much the Spanish inflation rate diverges from the European inflation rate; additionally, this variable has major implications for the economy.

This analysis aims to study whether these proposed variables lead to the same effects in all economic sectors. The study hypothesizes that, during the inflation announcement, not only is the increase or decrease of the inflation rate important, but so is the gap between Spanish and European inflation rates.

The event-study method literature (Barrett, Gosnell, and Heuson, 2004; Boyd, Hu, and Jagannathan, 2005; Díaz and Jareño, 2009 and 2013; Galati and Ho, 2003; Poitras, 2004; Telatar and Hasanov, 2006) includes this research and analyzes how unexpected inflation news affects stock returns according to sector in the Spanish economy. To this end, the study takes into account aspects such as the direction of the inflation surprises and the state of the economy. Additionally, this research contributes to the previous literature by including two innovative variables: the spread between Spanish and European inflation rates, and core and "non-core" inflation rate components.

The rest of the article unfolds follows. The second part includes literature review about event-study methodology. The third part reviews the data used the research: core 
inflation, spread between Spanish and European inflation rates, and stock returns. The fourth part shows an analysis of the short-run response of the stock returns by sector to unanticipated components of inflation announcements using the event-study methodology. The fifth part analyzes the long-run response. The sixth and last part includes a summary of the main results and conclusions.

\section{Literature review}

Using time-series event-study methods, much of the previous literature provides evidence that stock returns show significant responses to announcements of, among other results, profits, sales, and dividends: microeconomic news. Therefore, firmspecific news points to the probable path of future profits and thus affects the expected current value of future profits for stockholders. Some of the previous literature, however, defends the idea that stock returns react in response to macroeconomic surprises, which indicate the present state of the economy. Market participants take into account the publication of announcements about macroeconomic data, and this fact suggests a close relationship between movements of stock prices and these macroeconomic announcements.

Some studies use this approach to analyze repercussions of some macroeconomic announcements on returns of different market indexes, interest rates, or stocks. These studies examine the linearity and asymmetry of responses by considering macroeconomic news, the path, speed, and stability of responses. See, for instance, Andersen, Bollerslev, Diebold, and Vega (2003), Ewing and Payne (2005), Flannery and Protopapadakis (2002), Funke and Matsuda (2006), Gerlach (2007), and Pearce and Solakoglu (2007). 
When one analyzes the relationship between inflation rates and stock returns using the time-series event-study methodology, one should take into account the "efficient market" hypothesis. Considering this hypothesis allows for some assessment of the efficiency of financial markets in processing information. The "efficient market" hypothesis predicts that asset prices only respond to the unexpected component of new data, or "news."

According to this hypothesis, stock prices should only respond to unexpected changes in inflation announcements (which are really news), as stock prices already include the expected component of inflation announcements. Therefore, investors only respond to new and relevant information about the market, checking their expectations about future cash flows and company value; thus, stock prices reflect this information. This response to inflation news should occur immediately in an efficient market. If private information exists, stock prices reflect this response because the market reacts to news before its official publication. Finally, there is no consensus over the efficiency of the market. Nevertheless, most of the empirical literature supports the weak efficient market hypothesis, meaning that stock prices generally move whenever new and relevant information arrives in an inflation announcement. This adjustment also depends on the sector of activity and the stock size.

On the one hand, some studies assume that the interpretation of the macroeconomic announcements depends on the context in which the market receives the news; that is, the recent direction of the market or the recent state of the economy may influence investors' response to new information ("behavioral finance hypothesis," Veronesi, 1999). Studies such as those by Adams et al. (2004) and Veronesi (1999) report that the market should perceive any increase in inflation rates as "bad news" during expansions, as this situation could result in fears of an overheating economy. 
Nevertheless, during recessions, the market interprets the same increase as "good news" because economic agents think the economy is growing above expectations. That is, the positive inflation surprise could indicate both the end of the depression and higher forecasts of firms' cash flows; thus, one should expect an increase of stock prices and returns. Additionally, prices seem to overreact to "bad news" during good times. Docking and Koch (2005), who include market volatility in the interpretation of macroeconomic announcements, qualify this position.

By contrast, Estep and Hanson (1980) propose that the relationship between stock returns and unexpected inflation news depends on the ability of firms to transmit inflation shocks to the prices of the products and services sold by the company -"flowthrough hypothesis"- (Asikoglu and Ercan, 1992; Jareño, 2005; Jareño and Navarro, 2010; and Díaz and Jareño, 2013). Companies with a high flow-through coefficient should have the ability to reflect inflation rate changes in their product prices and thus "flow through" the effects of inflation to customers. These companies should be less inflation sensitive than companies with a low flow-through coefficient.

This study of the relationship between unanticipated inflation news and stock returns uses event-study methodology and assumes that investors' reactions could be sensitive to a combination of factors such as the nature of the news (good or bad), the state of the economy, or the flow-through ability of each sector of activity (Telatar and Hasanov, 2006).

Various recent analyses support the importance of the two selected variables: core inflation and the spread between Spanish and European inflation. In recent years, the main purpose of monetary policy has been price stability, and several central banks have implemented inflation-targeting policies. The previous literature has developed many methods of analyzing inflation, mainly either measures of core inflation or those 
derived from the harmonized index of consumer prices (HICP). For instance,

Cristadoro, Forni, Reichlin, and Veronese (2005) propose a new core inflation indicator for the Euro area, which they estimate by cleaning monthly price changes from shortrun volatility, idiosyncratic risk, and measurement errors. Hahn (2002) estimates core inflation in the Euro area using a structural vector autoregressive (VAR) approach; in his opinion, HICP sometimes proves a misleading indicator of monetary policy.

Considering that core inflation plays an important role in the deliberations of monetary policymakers, Vega and Wynne (2003) evaluate a number of measures of core inflation constructed using Euro-area data; they also focus on core measures derived from the HICP both because the European Central Bank has chosen to define its mandate for price stability in terms of this index and because this index is the only measure of consumer prices comparable across all members of the European Union. Cogley (2002) as well as Bagliano and Morana (2003) also propose some estimates of core inflation. In the Spanish case, López-Salido, Restoy, and Vallés (2005) study the determinants and macroeconomic implications of persistent inflation differentials in Spain within EMU, using some descriptive evidence and simulation exercises.

Outside the EU, other remarkable articles include Hogan, Johnson, and Laflèche (2001) and Bauer, Haltom, and Peterman (2004). The latter analyze the composition of inflation in the United States over time, and they examine the drop in core inflation over the analyzed period (2002-2003). Ultimately, they find that relative price changes of two components explain this decrease in core inflation. In addition, Peach, Rich, and Antoniades (2004) study the growing gap between the rate of increase of goods and services prices, as the latter prices tend to increase faster than the prices of goods. In this analysis, they use core inflation excluding food and energy components. Finally, 
Cecchetti and Wynne (2003) emphasize that HICP is very important when central banks define the monetary policy strategy and the main purpose of price stability.

The previous literature supports this study in its inclusion of these two variables (core inflation and the spread between Spanish and European inflation) and, specifically, its use of the spread between Spanish and European inflation rates as the main explanatory factor. This study goes further in proposing to split the total inflation rate into the core and "non-core" inflation rate components.

\section{Data}

\subsection{Core inflation}

Most of the literature considers core inflation (underlying inflation) to be the persistent component of the inflation rate, and this study obtains this inflation measure by removing the impact of goods and services with the most volatile prices from the CPI (Consumer Price Index), that is, non-manufactured products and energy. Therefore, core inflation is the long-run component and the most persistent trend in the total inflation rate.

To analyze the repercussion of unexpected inflation changes on stock returns, this research uses monthly announcements of the Spanish consumer price index (IPC) and distinguishes between underlying / core and "non-underlying / non-core" components -released by the Instituto Nacional de Estadística (INE) - and the exact date of each announcement between February 1995 and December 2004 in the short-term analysis (event-study analysis). Nevertheless, data from February 1993 factors into the long-term analysis.

The study features 119 IPC monthly announcements and, to remove the seasonal component of the IPC series, uses a year-to-year inflation rate. Therefore, the study obtains the monthly inflation rate after seasonal adjustment $\left(\pi_{t}\right)$ using the following expression:

$$
\pi_{t}=\frac{I P C_{t}-I P C_{t-12}}{I P C_{t-12}}
$$

where $I P C_{t}$ is the consumer price index at time $t$. 
Figure 1 plots the evolution of the total inflation rate and its two components, core and "non-core" inflation and shows the non-stationarity of the three variables. ${ }^{1}$ [Figure 1 here]

Following Leiser and Drori (2005), this research uses a nä̈ve model ("myopic expectations") that assumes that the best forecast of the inflation rate coincides with the information of the previous month. ${ }^{2}$ Therefore, unexpected changes in inflation rate equal total changes in the expected inflation rate, $\Delta E_{t}\left(\pi_{t, t+12}\right)$, that is,

$$
\Delta E_{t}\left(\pi_{t, t+12}\right)=\left\lfloor E_{t}\left(\pi_{t, t+12}\right)-E_{t-1}\left(\pi_{t-1, t+11}\right)\right]=\pi_{t-12, t}-\pi_{t-13, t-1} .
$$

Additionally, this research can decompose the total inflation rate into two parts, core and "non-core" inflation. Thus, the following equation can express the total change of expected inflation rate:

$$
\Delta E_{t}\left(\pi_{t, t+12}\right)=\Delta E_{t}\left(\pi_{t, t+12}^{C}\right)+\Delta E_{t}\left(\pi_{t, t+12}^{N C}\right),
$$

where $\pi_{t, t+12}^{C}$ is core inflation rate and $\pi_{t, t+12}^{N C}$ is "non-core" inflation.

Figure 2 displays the evolution of the inflation rate changes and its core and "non-core" components. Therefore, these series are stationary in mean.

[Figure 2 here]

\subsection{Spread between Spanish and Euro Area HICP}

This work also uses data about the Spanish and Euro area harmonized index of consumer prices (HIPC) released by the statistical office of the European communities (EUROSTAT) and hypothesizes that the exact date of this announcement coincides with the Spanish core inflation announcement. ${ }^{3}$

The HICP data cover the same period as core inflation data, that is, from February 1995 to December 2004, so this work relies on 119 HICP monthly announcements. To remove the seasonal component of the HICP series, this study uses a year-to-year inflation rate. Therefore, the work obtains the Spanish and Euro Area monthly harmonized inflation rate after seasonal adjustment $\left(\pi_{t}\right)$ using the following expression:

$$
\pi_{t}=\frac{H I C P_{t}-H I C P_{t-12}}{H I C P_{t-12}},
$$

where $\mathrm{HICP}_{t}$ is the harmonized index of consumer prices at time $t$.

Figure 3 plots the evolution of Spanish and European harmonized inflation rates and the spread between the two. This study obtains the latter as follows:

$$
E_{t}\left(\operatorname{spread}_{t, t+12}\right)=E_{t}\left(\pi_{t, t+12}^{S}\right)-E_{t}\left(\pi_{t, t+12}^{E A}\right),
$$


where $\pi_{t, t+12}^{S}$ is the Spanish and $\pi^{E A}{ }_{t, t+12}$ the Euro-Area harmonized inflation rate. This spread is normally positive in this study's sample, so the Spanish harmonized inflation rate is higher than the European one.

[Figure 3 here]

The analysis of this work focuses on examining the repercussion of changes in the spread between Spanish and European harmonized inflation rates on stock returns. Therefore, the study again assumes economic agents with myopic expectations, which Leiser and Drori (2005) consider a realistic hypothesis. Thus, the best forecast of harmonized inflation rate coincides with the information of the previous month:

$$
E_{t}\left(\pi_{t, t+12}\right)=\pi_{t-12, t} .
$$

One can express changes in the spread between the Spanish and Euro-Area harmonized inflation rates as follows:

$$
\Delta E_{t}\left(\operatorname{spread}_{t, t+12}\right)=\Delta E_{t}\left(\pi_{t, t+12}^{S}\right)-\Delta E_{t}\left(\pi_{t, t+12}^{E A}\right)
$$

One can observe the evolution of changes in this spread in Figure 4, which indicates that the change in this study's spread is a stationary series. This work assumes that positive changes in this spread convey higher changes in the Spanish HICP than in the European HICP and vice versa.

[Figure 4 here]

\subsection{Returns by sector}

For the same sample period of inflation data (February 1995 to December 2004), this study obtains daily (close-to-close) returns of 115 individual companies traded on the electronic system of the Spanish Stock Exchange, SIBE. ${ }^{4}$ This work considers all Spanish companies quoted during some period in the sample to avoid a possible survival bias of considering only the companies that cover the whole sample. Also, this work removes foreign companies quoted in the Spanish Stock Exchange from the sample. This study uses daily data; thus, this research can isolate the IPC announcement effects from any other macroeconomic announcements during the month. ${ }^{5}$ Finally, this study verifies that, in general, the Spanish Economy does not publish announcements 
about other macroeconomic magnitudes on the announcement day and during the event window.

This study's sample includes 115 Spanish companies, creating daily equally weighted sector-based stock portfolio returns, aggregating by industry on an equally weighted basis to obtain the series of monthly returns for each sector. ${ }^{6}$ The research uses the Madrid Stock Exchange sector definition scheme (see Table 1) and calculates a daily equally weighted total market return as a proxy of the market return (M). ${ }^{7}$

[Table 1 here]

\section{Short-term response of stock returns to inflation announcements}

Most of the literature about the event-study methodology focuses not only on the announcement day but also on the two previous and two following days. Therefore, this study builds an "event window" that contains five days: the announcement day $\left(\mathrm{t}_{\mathrm{j}}\right)$, two days before the announcement day or "pre-announcement period" ( $\mathrm{t}_{\mathrm{j}}-1$ and $\left.\mathrm{t}_{\mathrm{j}}-2\right)$, and two days after the announcement or "post-announcement period" $\left(t_{j}+1\right.$ and $\left.t_{j}+2\right)$. The "pre-event window" contains the days between two consecutive event windows $\left(t_{j-1}+3\right.$, $\left.\mathrm{t}_{\mathrm{j}}-3\right){ }^{8}$

This work estimates returns corrected by the expected return, that is, abnormal returns, to eliminate possible effects beyond inflation announcements. The literature uses multiple alternative approximations to obtain the expected return, but all of them base themselves on pricing models (the market model, the Capital Asset Pricing Model, Conditional CAPM, the Fama and French three-factor models, etc.). Thus, this study avoids making the results conditional on the hypotheses of the pricing model. Rather, this study estimates the expected return with its unbiased estimator; that is, this work computes abnormal returns, $a r_{i}(t)$, for each day inside the event window, from two days 
before $\left(t_{\mathrm{j}}-2\right)$ to two days after $\left(t_{\mathrm{j}}+2\right)$ the IPC announcement $\left(t_{\mathrm{j}}\right)$. The abnormal return of sector $i$ on the day $t_{j}+k, a r_{i}\left(t_{j}+k\right),(i=\mathrm{S} 1, \mathrm{~S} 2, \ldots, \mathrm{S} 6, \mathrm{M}$; and $k=-2, \ldots,+2)$ constitutes the difference between the observed return (ex-post return) on day $t_{j}+k, r_{i}\left(t_{j}+k\right)$ and the expected return of the sector in the absence of an inflation event, $E\left[r_{i}\left(t_{j}\right)\right]$. One can estimate this expected return is as the average daily return of the sector during the days out of the last four event windows:

$$
\operatorname{ar}_{i}\left(t_{j}+k\right)=r_{i}\left(t_{j}+k\right)-E\left[r_{i}\left(t_{j}\right)\right]=r_{i}\left(t_{j}+k\right)-\frac{\sum_{\tau=t_{j-3}+3}^{t_{j}-3} r_{i}(\tau)}{\sum_{\tau=t_{j-3}+3}^{t_{j}-3} t_{\tau}}
$$

where $\tau \notin\left(t_{h}-2, t_{h}+2\right)$ in the last four announcements is $(h=-3,-2,-1,0)$.

Having calculated these abnormal returns by sector, which homogenizes the average returns of different sectors, the next part of this study analyzes the existence of some behavioral norms by taking into account the sector of activity.

\subsection{Response of stock returns by sector to inflation announcements, taking into account core and "non-core" inflation rate components}

This section proposes this work's model for analyzing the abnormal returns response to inflation rate movements, distinguishing between core (without taking into account non-manufactured products and energy) and "non-core" inflation rates.

The estimated model is as follows:

$$
a r_{j}(t)=\alpha_{j}+\beta_{j 1} \cdot \Delta \pi_{t}^{C}+\beta_{j 2} \cdot \Delta \pi_{t}^{N C}+u_{j t},
$$

where $\operatorname{ar}_{j}(t)$ represents the abnormal returns of sector $j$ on each period $t, \pi^{C}{ }_{t}$ is core

inflation, $\pi^{N C}$ is the "non-core" component of the inflation rate, and $u_{j t}$ is the error term of sector $j$ (assuming “myopic expectations”). 
Table 2 shows the results of the estimation of model 10, using the "seemingly unrelated regression" technique (SUR) and taking into account heteroskedasticity and the possible contemporaneous correlation in the error terms across equations.

\section{[Table 2 here]}

These results resemble those of Díaz and Jareño (2009 and 2013), albeit this research decomposes the inflation rate into core and "non-core" inflation rate components. This study finds relevant differences in the sign and value of the estimated coefficients of different sectors, mainly in the pre- and post-announcement periods.

As expected, this study finds a stable behavior among sectors, characterized by a negative response of the stock returns to inflation changes when focusing on "non-core" inflation (i.e., the most volatile component of the inflation rate). Also, this negative response is statistically significant in the pre-announcement period (two previous days) in sector 2, "Basic Materials, Industry and Construction," and in the post-announcement period (two following days) in sector 1, "Oil and Energy," sector 2 and the total market (M).

On the other hand, all sectors demonstrate positive responses to inflation changes if one analyzes core inflation in the two days before the announcement (preannouncement period). On the announcement day, the stock-return response is also positive, except in sectors 5 and 6, "Financial and Real State Services" and "Technology and Telecommunications," respectively. Finally, in the two days after the announcement (post-announcement period), three sectors show a positive response (S1, S4: "Consumer Services," and S5) to core inflation movements, whereas the other three sectors show a negative response (S2, S3: "Consumer Goods," and S6) to core inflation movements. 
Therefore, most stock returns by sector mainly show negative coefficients to "non-core" inflation changes, so companies of these sectors seem to have low flowthrough ability with regard to the "non-core" component of the inflation rate (the most volatile component). Sector 2 appears the most sensitive sector to "non-core" inflation changes, showing a high level of statistical significance.

\section{Response of stock returns by sector to inflation announcements, taking into account core and "non-core" inflation rate components and the spread between Spanish and European HICP, according to the direction of the news and the state of the economy}

This study's analysis also contributes to the literature in this area because this work includes the spread between Spanish and Euro-Area harmonized inflation rates. This research proposes an innovative explanatory variable in its analysis of the stock return response by sector: the distance or differential between the HICP registered in Spain and the Euro Area. Therefore, the analysis of this study features a measure of Spain's approximation to or distance from the European inflation level.

First, this study tracks the correlation matrix between the explanatory variables and observes a high correlation (near 40 per cent) between changes in both the spread and the two components of the inflation rate (core and "non-core"). To avoid the possible existence of multicollinearity between the explanatory variables, much previous literature usually uses an orthogonalization procedure. Therefore, this study regresses its spread measure on a constant and the unexpected changes of the two inflation rate components (core and "non-core") using OLS (ordinary least squares) estimation. Therefore, the present research isolates the effect of each factor, and the residuals capture the movement that remains: ${ }^{9}$ 


$$
\Delta \operatorname{spread}_{t}=a+b \cdot \Delta \pi_{t}^{C}+c \cdot \Delta \pi_{t}^{N C}+\varepsilon_{t} .
$$

Many previous studies show that stock returns do not respond significantly to unexpected inflation changes, but they do not distinguish between positive and negative surprises, indicating an insignificant net effect. Andersen et al. (2003) argue that "bad news" has greater impact than "good news" after macroeconomic announcements, that is, that a sign effect characterizes the adjustment response pattern of foreign exchange rates. This study thus considers positive inflation surprises ("bad news" in the literature, i.e., total inflation higher than expected inflation) and negative surprises ("good news," i.e., total inflation lower than anticipated inflation) separately.

To check these asymmetric effects, this study applies two modifiers to its dummy variables. These modifiers represent a positive spread (between Spanish and European inflation rates) or "bad news" $\left(D^{+}{ }^{+}\right)$and a negative spread or "good news" $(D$. ), and they take on the following values:

$$
D_{\bullet}^{+}=\left\langle\begin{array}{l}
1, \text { if } \Delta \text { spread }_{t}>0 \\
0, \text { if } \Delta \text { spread }_{t}<0
\end{array} \quad D_{\bullet}^{-}=\left\langle\begin{array}{l}
1, \text { if } \Delta \text { spread }_{t}<0 \\
0, \text { if } \Delta \text { spread }_{t}>0
\end{array} .\right.\right.
$$

Authors such as Adams et al. (2004), Docking and Koch (2005), and Veronesi (1999), using arguments of the "behavioral finance" hypothesis (BFH), declare that the interpretation of macroeconomic announcements depends on the context in which the market receives the news. In the case of inflation rate news, one should perceive any increase in this variable as "bad news" during expansions, as this bad news could result in fears of an overheating economy. Nevertheless, during recessions, one could consider the same increase "good news" because economic agents think that the economy is growing above expectations. This situation could indicate higher forecasts of the firms' cash flows, so one should expect an increase of stock prices and returns. 
The present research examines a possible different response of abnormal stock returns by sector in the Spanish economy to unexpected changes in the spread between Spanish and Euro-Area inflation rates, depending on the direction of the inflation surprises and the state of the economy. Therefore, this study, in an effort to classify the economic activity by levels, follows McQueen and Roley’s (1993) methodology. ${ }^{10}$

To control for the state of the economy, this study includes two modifiers in the dummy variables: $D_{H}$ ("High") and $D_{N H}$ ("Non-High"). Each dummy is equal to one if economic activity in month $t$ belongs to the corresponding state ("high" in the first one, and "medium" or "low" in the second one) and zero otherwise. ${ }^{11}$ As in previous research, the present research combines the medium and low states of the economy to have enough observations.

This study checks for a possible different response of abnormal stock returns by sector in the Spanish economy to changes in its spread measure depending on the direction of the inflation surprises and the state of the economy (i.e., accounting for whether Spanish inflation is nearer to or farther from Euro-Area inflation). This research assumes that investors' interpretations of inflation announcements differ between periods of expansion and recession. Therefore, this study proposes the following model:

$$
\begin{aligned}
\operatorname{ar}_{j}(t)= & \alpha_{j}+\beta_{j 1} \cdot \Delta \pi_{t}^{C}+\beta_{j 2} \cdot \Delta \pi_{t}^{N C}+\beta_{j 3} \cdot D_{H}^{+} \cdot\left|\Delta \operatorname{spread}_{t}\right|+\beta_{j 4} \cdot D_{N H}^{+} \cdot\left|\Delta \operatorname{spread}_{t}\right|+ \\
& +\beta_{j 5} \cdot D_{H}^{-} \cdot\left|\Delta \operatorname{spread}_{t}\right|+\beta_{j 6} \cdot D_{N H}^{-} \cdot \mid \Delta \text { spread }_{t} \mid+u_{j t}
\end{aligned}
$$

where $\Delta$ spread $_{t}$ represents changes in the spread between Spanish and European inflation, both harmonized, assuming that total changes correspond to unexpected changes (myopic expectations).

Four dummy variables account for all the possible combinations between the two considered factors. On one hand, superscript + in dummy variables $\left(D_{.^{+}}^{+}\right)$denotes 
positive inflation spreads (“bad news”, i.e., Spanish HICP higher than Euro-Area HICP), and superscript - (D.) denotes negative inflation spreads ("good news", i.e., Spanish inflation lower than European inflation). On the other hand, the subscripts $H$ $\left(D_{H}{ }^{\circ}\right)$ and $N H\left(D_{N H}{ }^{\circ}\right)$ indicate a high and non-high state of economic activity, respectively. Each dummy variable takes on the value 1 when the two conditions take place simultaneously.

This study estimates model 11 for all sectors and for the whole market simultaneously as a system of seemingly unrelated regressions (SUR). This technique accounts for heteroskedasticity and the possible contemporaneous correlation in the error terms across equations. ${ }^{12}$ Also, this research expresses the change in the spread between Spanish and European inflation in terms of absolute values to facilitate the interpretation of the results.

This study reports results for this regression, which takes into account the direction of the news and the state of the economy (model 11), Table 3.

This analysis increases coefficient $\mathrm{R}^{2}$ so that the model can explain a higher percentage of the variations experienced by returns of each sector.

Stock returns respond the same (in sign and significance level) to changes in core and "non-core" inflation with respect to the previous analysis.

\section{[Table 3 here]}

A positive, if generally insignificant, response of stock returns to core inflation movements in the pre-announcement period and on the announcement day summarizes this behavior of stock returns by sector to changes in both inflation components. But in the post-announcement period, this study observes positive responses of abnormal returns to the core inflation component for three sectors (1, 4 and 5) and negative responses for the other three sectors (2, 3 and 6). Regarding the "non-core" inflation 
changes, the stock return response is negative for the entire event window, although coefficients are only statistically significant in the pre- and post-announcement periods.

On the days before the announcement, sectors 2 and 5 and the whole market (M) show a negative and significant response to changes in the "non-core" inflation component. On the days after the announcement, sectors 1,2 and 4 and $\mathrm{M}$ show the same negative and significant response to shocks in this more volatile component of inflation rates.

Focusing attention on this study's other innovative variable, the change in the spread between Spanish and European HICP, most of the sectors have positive and insignificant coefficients in the pre-announcement period. However sectors 1, 3 and 5, "Oil and Energy," "Consumer Goods" and "Financial and Real Estate Services," and the whole market (M) show highly significant coefficients when the spread is positive in non-high states of the economy $(+, N H)$. According to this sign, these sectors and the whole market interpret the fact that the Spanish inflation rate is higher than the EuroArea inflation rate in medium and low states of activity as good news for stock returns, for this difference in inflation rates means that the Spanish economy is growing more than the European economies. Also, these sectors and the whole market associate this period of higher economic growth with a better ability of firms to transfer inflation shocks to prices of products and services, that is, they have "flow-through" capability, which seems to depend on the economic cycle. Therefore, positive changes in this study's spread measure during non-high states of the economy have a positive and significant impact on stock returns.

Using arguments of the "behavioral finance" hypothesis, the market should perceive any increase in this study's spread variable as "good news" during medium and 
low states of economic activity $(+, N H)$, because economic agents think that the Spanish economy is growing above the expectations for the Euro Area as a whole.

On the announcement day, most of the sectors show insignificant responses to spread changes, although the present research emphasizes the homogeneity in the sign of the coefficients that accompany negative changes in this study's spread measure (Spanish inflation is close to Euro Area inflation) during non-high states of economic activity (-, $N H)$. Sectors 1, 2, 4 and 6, "Oil and Energy," "Basic Materials, Industry and Construction," "Consumer Services" and "Technology and Telecommunications," and the whole market $(\mathrm{M})$ show positive responses in this scenario. According to the "flowthrough capability" hypothesis, this ability seems to depend on the economic cycle; thus, when Spanish inflation is lower than European inflation, the market interprets this situation as good news in this period. A general reduced capability to transfer inflation shocks to output prices characterizes these kinds of periods.

This research highlights the statistically significant behavior displayed by sector 3, "Consumer Goods," which shows a negative response to positive changes in this study's spread measure during expansions because of the traditional difficulties of this sector subject to strong foreign competition. This research also interprets a positive spread in medium and low states of the economy as good news, a sign that Spain is starting a phase characterized by high economic growth (higher than in the Euro Area), indicating that companies demonstrate high flow-through capability. Therefore, stock returns significantly increase in this scenario. Finally, sector 3 is the only sector that shows a significantly different response across scenarios, according to the Wald test.

Finally, in the post-announcement period, the sign of the response among different sectors is not clear, and, in general, this response is not statistically significant. Nevertheless, all sectors demonstrate stable behavior: a positive response to negative 
surprises in this study's spread measure (Spanish inflation converges with Euro-Area inflation) during non-high states of economic activity (-, $\mathrm{NH})$. Therefore, this research associates the period of "non-high" economic growth with a reduced "flow-through" capability of firms; therefore, negative changes in this study's spread measure (Spanish inflation close to Euro-Area inflation) during non-high states of the economy positively impact stock returns and mean "good news." This research also calls attention to a negative and significant response of the stock returns from sector 1, "Oil and Energy," if Spanish inflation converges with European inflation during expansions.

Companies related to crude oil determine, to some extent, the trend of the inflation rate in each country. Thus, if the inflation rate decreases and converges with the Euro-Area inflation rate, one could construe this situation as "bad news," which, in turn, negatively affects sector stock returns.

An intersectoral test of the equality of response in each scenario does not reject the null hypothesis. Nevertheless, stock returns by sectors show significant different responses both to positive changes in this study's spread measure during non-high states of the economy ( $\chi^{2}$ statistic in Wald test, 26.07 , rejects the null hypothesis of equality of coefficients among sectors at the 1 per cent significance level) as well as to negative changes in the spread measure during expansions $\left(\chi^{2}=12.90\right.$, at the 5 per cent significance level).

\section{Long-term response of stock returns to inflation announcements}

To analyze the repercussion of unexpected inflation changes on stock returns by sector in the long term, distinguishing between underlying / core and "non-underlying / non-core" inflation rate components and taking into account the spread between Spanish and European inflation rates, this study uses monthly stock returns by sector in the 
Spanish Economy. This research aggregates data (from 115 companies) by industry on an equally weighted basis to obtain the series of monthly returns for each sector from February 1993 to December 2004. This study uses the Madrid Stock Exchange sector definition scheme and calculates a monthly equally weighted total market return as a proxy for the market return $(\mathrm{M}){ }^{13}$

This study proposes the following model:

$$
\begin{aligned}
r_{j t}=\alpha_{j}+\beta_{j 1} \cdot \Delta \pi_{t}^{C}+ & \beta_{j 2} \cdot \Delta \pi_{t}^{N C}+\beta_{j 3} \cdot \Delta \text { spread }_{t}+\beta_{j 4} \cdot \Delta \pi_{t-1}^{C}+ \\
& +\beta_{j 5} \cdot \Delta \pi_{t-1}^{N C}+\beta_{j 6} \cdot \Delta \text { spread }_{t-1}+u_{j t},
\end{aligned}
$$

where $r_{j t}$ is the monthly stock return of sector $j$ in period $t$. This work also includes lagged values of core and "non-core" inflation rate components and the spread between Spanish and European inflation rates. Table 4 reports results using SUR estimates.

\section{[Table 4 here]}

The most important results follow. On the one hand, this research finds significant negative responses of stock returns by sector to the lagged core inflation component (i.e, the structural component of the inflation rate). This result appears in all sectors (except sector 3, "Consumer Goods") and means that the structural part of the inflation rate affects stock returns principally in the long term and after the announcement of the inflation rate (lagged core inflation).

On the other hand, the stock return responds negatively to current "non-core" inflation changes (though coefficients are only statistically significant in the case of sector 2, "Basic Materials, Industry and Construction"). Therefore, the most volatile component of the inflation rate affects stock returns by sector at the very moment the "non-core" inflation change occurs. This effect is also significant in the case of sector 2. 
Regarding this study's spread measure, which to some extent can reflect the competitiveness level of each country, the coefficient sign is unstable and statistically insignificant.

Finally, the Wald test of the equality of intersectoral responses in each scenario rejects the null hypothesis at the 5 per cent significance level for changes in the lagged "non-core" inflation rate component and in this study's lagged spread measure.

\section{Summary and conclusions}

Many researches analyze the repercussion of macroeconomic announcements on returns of different market indexes, interest rates or stock returns: Adams et al. (2004), Boyd et al. (2005), Docking and Koch (2005), Mestel and Gurgul (2003), Funke and Matsuda (2006), and Pearce and Solakoglu (2007). This study contributes to the existing literature by proposing innovative explanatory variables with which to analyze how unexpected inflation news affects stock returns by sector in the Spanish economy: the spread between Spanish and European inflation rates and core and "non-core" inflation rate components.

Some recent studies, such as Cecchetti and Wynne (2003), Matilla-García (2005), Wynne and Rodríguez-Palenzuela (2004), evidence the importance of the selected variables for decisions on monetary policy. The spread between Spanish and European inflation rates, this study's main explanatory factor, reveals the effect of the differential between Spanish inflation and Euro-Area inflation on stock returns by sector.

Regarding the short-term response of stock returns to inflation announcements, the most volatile "non-core" component of the inflation rate significantly and negatively affects sector returns; this research would expect the above mentioned effect because 
the "non-core" component is the temporary element of the inflation rate. Adams et al. (2004), Jareño (2008), and Joyce and Read (2002) show a negative relationship between the total inflation rate and stock returns without splitting this inflation rate into core and "non-core" components.

Considering the direction of the inflation surprises and the state of the economy, on the announcement day, the present results show that negative changes in this study's spread measure have a positive effect on stock returns by sector in non-high states of the economy. In these kinds of periods, according to the "flow-through capability" hypothesis, this ability to reflect inflation rate changes in their product prices seems to depend on the economic cycle. Thus, when Spanish inflation is lower than European inflation, the market interprets this situation as good news in this period, which displays a reduced capability to transfer inflation shocks to output prices. The most sensitive sectors include "Oil and Energy," "Basic Materials, Industry and Construction," "Consumer Services" and "Technology and Telecommunications," for they show a statistically significant response to changes in the spread measure.

Also, in the post-announcement period, positive changes in the spread measure affect sector 3 negatively during expansions and positively in non-high states of the economy, and, in both cases, the results are significant. The market interprets the fact that the Spanish inflation rate is higher than the Euro-Area inflation rate as "bad news" only in high states. Companies seem to face difficulties in transferring higher Spanish shocks to their input prices than they do in the case of European inflation shocks. This result completely coincides with the traditional difficulties (including being subject to strong foreign competition) of sector 3, "Consumer Goods." 
Finally, in the long-term analysis, changes in the "core" inflation rate component negatively affect stock returns by sector. This study shows that the structural part of the inflation rate has significant negative effects in the long term, as one would expect.

In the short term, more changeable indicators (the "non-core" inflation rate component and the spread between Spanish and European inflation rates) affect stock returns by sector, whereas in the long term, the structural indicator (core inflation) shows a higher effect on stock returns by sector. 


\section{References}

Adams, G., McQueen, G. and R. Wood (2004): 'The Effects of Inflation News on High Frequency Stock Returns', Journal of Business, Vol. 77, N 3, pp. 547-574.

Altissimo, F., Benigno, P. and Rodríguez Palenzuela, D. (2005): 'Long-run Determinants of Inflation Differentials in a Monetary Union', Moneda y Crédito, $\mathrm{N}^{\mathrm{o}}$ 220, pp. 203-260.

Andersen, T. G., Bollerslev, T., Diebold, X. and C. Vega (2003): 'Micro Effects of Macro Announcements: Real-Time Price Discovery in Foreign Exchange', The American Economic Review, Vol. 93, № 1, pp. 38-62.

Asikoglu, Y. and Ercan, M. R. (1992): 'Inflation Flow-Through and Stock Prices'. Journal of Portfolio Management, Vol. 18, № 3, pp. 63-68.

Bagliano, F. C. and Morana, C. (2003): 'A common trends model of UK core inflation', Empirical Economics, Vol. 28, № 1, pp. 157-172.

Barrett, W. B., Gosnell, T. F. and Heuson, A. J. (2004): 'Term-Structure Factor Shifts and Economic News', Financial Analysts Journal, Vol. 80, № 5, pp. 81-94.

Bauer, A., Haltom, N. and Peterman, W. (2004): 'Examining Contributions to Core Consumer Inflation Measures', Working Paper 2004-7 Federal Reserve Bank of Atlanta.

Boyd, J. H., Hu, J. and Jagannathan, R. (2005): ‘The Stock Market's Reaction to Unemployment News: Why Bad News is Usually Good for Stocks', The Journal of Finance, Vol. 60, № 2, pp. 649-672. 
Cecchetti, S. G. and Wynne, M. A. (2003): 'Inflation measurement and the ECB's pursuit of price stability: a first assessment', Economic Policy, Vol. 18, № 37, pp. 395434.

Cristadoro, R., Forni, M., Reichlin, L. and Veronese, G. (2005): ‘A Core Inflation Indicator for the Euro Area', Journal of Money, Credit and Banking, Vol. 37, No 3, pp. 539-560.

Díaz, A. and Jareño, F. (2009): 'Explanatory factors of the inflation news impact on stock returns by sector: the Spanish case', Research in International Business and Finance, Vol. 23, № 3, pp. 349-368.

Díaz, A. and Jareño, F. (2013): 'Inflation News and Stock Returns: Market Direction and Flow-Through Ability', Empirical Economics, Vol. 44, N² 22, pp. 775-798.

Docking, D. S. and Koch, P. D. (2005): 'Sensitivity of investor reaction to market direction and volatility: dividend change announcements', The Journal of Financial Research, Vol. XXVIII, No 1, pp. 21-40.

Estep, T. and Hanson, N. (1980): The Valuation of Financial Assets in Inflation, New York: Salomon Brothers.

Ewing, B.T. and Payne J.E. (2005): 'The response of real estate investment trust returns to macroeconomic shocks', Journal of Business Research, N 58, pp. 293-300.

Flannery, M. J. and A. A. Protopapadakis (2002): 'Macroeconomic Factors Do Influence Aggregate Stock Returns', The Review of Financial Studies, Vol. 15, No 3, pp. 751-782. 
Funke, N. and Matsuda, A. (2006): 'Macroeconomic News and Stock Returns in the United States and Germany', German Economic Review, Vol. 7, № 2, pp. 189-210.

Galati, G. and Ho, C. (2003): 'Macroeconomic News and the Euro/Dollar Exchange Rate', Economic Notes, Vol. 32, No 3, pp. 371-398.

Gerlach, J. R. (2007): 'Macroeconomic News and Stock Market Calendar and Weather Anomalies', Journal of Financial Research, Vol. 30, № 2, pp. 283-300.

Hahn, E. (2002): 'Core Inflation in the Euro Area: Evidence from the Structural VAR Approach', CFS (Centre for Financial Studies) Working paper $N^{o}$ 2001/09.

Hogan, S., Johnson, M. and Laflèche, T. (2001): 'Core Inflation', Technical Report $N^{o}$ 89 Bank of Canada.

Jareño, F. (2005): 'Flow-through capability: The Spanish case', Journal of Asset Management, Vol. 6, N 3, pp. 191-205.

Jareño, F. (2008): ‘Spanish Stock Market Sensitivity to Real Interest and Inflation Rates. An Extension of the Stone Two-Factor Model with Factors of the Fama and French Three-Factor Model', Applied Economics, Vol. 40, № 24, pp. 3159-3171.

Jareño, F. and Navarro E. (2010): 'Interest rate risk and inflation shocks', European Journal of Operational Research, Vol. 201, № 2, pp. 337-348.

Joyce, M. A. S. and Read, V. (2002): 'Asset price reactions to RPI announcements', Applied Financial Economics, Vol. 12, pp. 253-270.

Leibowitz, M. L. and Kogelman, S. (1990): 'Inside the P/E Ratio: The Franchise Factor', Financial Analysts Journal, November-December, Vol. 46, № 6, pp. 17-35. 
Leibowitz, M. L. and Kogelman, S. (1993): 'Resolving the Equity Duration Paradox', Financial Analysts Journal, January-February, Vol. 49, № 1, pp. 51-64.

Leiser, D. and Drori, S. (2005): 'Naïve understanding of inflation', Journal of SocioEconomics, Vol. 34, pp. 179-198.

López-Salido, J. D., Restoy, F. and Vallés J. (2005): 'Inflation Differentials in EMU: the Spanish case', Moneda y Crédito, № 220, pp. 55-104.

Matilla-García, M. (2005): 'A SVAR model for estimating core inflation in the Euro zone', Applied Economics Letters, Vol. 12, № 3, pp. 149-154.

Mestel, R. and H. Gurgul (2003): 'ARIMA Modeling of Event Induced Stock Price Reactions in Austria', Central European Journal of Operations Research, Vol. 11, No 4 (December), pp. 317-334.

McQueen, G. and Roley, V. V. (1993): ‘Stock Prices, News, and Business Conditions', The Review of Financial Studies, Vol. 6, № 3, pp. 683-707.

Peach, R. W., Rich, R. and Antoniades, A. (2004): 'The Historical and Recent Behavior of Goods and Services Inflation', FRBNY Economic Policy Review.

Pearce, D. K and Solakoglu, M. N. (2007): 'Macroeconomic News and Exchange Rates', Journal of International Financial Markets, Institutions \& Money, Vol. 17, № 4, pp. 307-325.

Poitras, M. (2004): 'The Impact of Macroeconomic Announcements on Stock Prices: In Search of State Dependence', Southern Economic Journal, Vol. 70, N 3, pp. 549-565. 
Telatar, E. and M. Hasanov (2006): 'The asymmetric effects of monetary shocks: the case of Turkey', Applied Economics, Vol. 38, № 18, pp. 2199-2208.

Vega, J. L. and Wynne, M. (2003): 'A First Assessment of Some Measures of Core

Inflation for the Euro Area', German Economic Review, Vol. 4, No 3, pp. 269-306.

Veronesi, P. (1999): 'Stock Market Overreaction to Bad News in Good Times: A

Rational Expectations Equilibrium Model', The Review of Financial Studies, Vol. 12,

№ 5, pp. 975-1007.

Wynne, M. and Rodríguez-Palenzuela, D. (2004): 'Measurement bias in the HICP:

What do we know and what do we need to know?' Journal of Economic Surveys, Vol.

$18, \mathrm{~N}^{\mathrm{o}} 1, \mathrm{pp} .79-112$.

\section{Notes}

\footnotetext{
${ }^{1}$ This research uses the classical unit root tests, which are augmented Dickey-Fuller, Phillips-Perron and KPSS (Kwiatkowski-Phillips-Schmidt-Shin) tests. This report does not present these results for the sake of space.

${ }^{2}$ The inflation rate is not stationary in mean, $\mathrm{I}(1)$, and random walk, because ARIMA $(0,1,0)$ process provides the best possible results, applying the Akaike information criterion (AIC).

${ }^{3}$ This assumption is very realistic because the INE normally releases the CPI and HICP on the same date.

${ }^{4}$ This study uses split-adjusted stock prices.

5 To see advantages of daily data against monthly data, see Adams et al. (2004), Flannery and Protopapadakis (2002), and McQueen and Roley (1993).

${ }^{6}$ This study assumes that the Spanish Economy publishes inflation announcements before the closing time of the stock exchange market.

${ }^{7}$ The classical unit-root tests confirm that these series are stationary in mean. This study does not report these results in the interest of brevity.

${ }^{8}$ This study assumes that this number is enough to guarantee an acceptable accuracy level without important changes in the underlying probability distribution (Mestel and Gurgul, 2003).

${ }^{9}$ To manage the length of this article, this study does not present these results. The spread measure herein only takes into account those changes not correlated with core and "non-core" inflation rate components.

${ }^{10}$ Please, see supplementary material 2 for a more detailed explanation.

${ }^{11}$ High growth characterizes this study's sample period except for 1993, which evinces an economic crisis.

${ }^{12}$ Because the right-hand-side variables are the same in all the equations, the SUR estimates using GMM are the same as OLS estimates; only the standard errors differ. This work estimates the equations as SUR only to recognize explicitly that residuals are likely to be correlated.
} 
${ }^{13}$ The minimum number of companies incorporated into each sector follows: sector 1 (7), sector 2 (15), sector 3 (7), sector 4 (4), sector 5 (19), sector 6 (2) and the whole market (54). 
Table 1. Number of companies included in this analysis and the sector to which they belong

\begin{tabular}{|c|c|c|}
\hline Sector Name & $\begin{array}{c}\text { Number of } \\
\text { firms }\end{array}$ & Subsectors \\
\hline Sector 1: Oil and Energy & 8 & $\begin{array}{l}\text { 1.1.: Oil } \\
\text { 1.2.: Electricity and Gas } \\
\text { 1.3.: Water and Others }\end{array}$ \\
\hline $\begin{array}{c}\text { Sector 2: Basic Materials, } \\
\text { Industry and } \\
\text { Construction }\end{array}$ & 30 & $\begin{array}{l}\text { 2.1.: Minerals, Metals and Transformation } \\
\text { 2.2.: Manufacture and assembly of capital assets } \\
\text { 2.3.: Building Industry } \\
\text { 2.4.: Building Materials } \\
\text { 2.5.: Chemistry Industry } \\
\text { 2.6.: Engineering and Others } \\
\text { 2.7.: Aerospace }\end{array}$ \\
\hline Sector 3: Consumer Goods & 26 & $\begin{array}{l}\text { 3.1.: Food and Drinks } \\
\text { 3.2.: Textile, Clothes and Footwear } \\
\text { 3.3.: Paper and Graphic Arts } \\
\text { 3.4.: Car } \\
\text { 3.5.: Pharmaceutical Products and } \\
\quad \text { Biotechnology } \\
\text { 3.6.: Other Consumer Goods }\end{array}$ \\
\hline Sector 4: Consumer Services & 19 & $\begin{array}{l}\text { 4.1.: Tourism and Hotel and Catering Business } \\
\text { 4.2.: Retail Trade } \\
\text { 4.3.: Media and Advertising } \\
\text { 4.4.: Transport and Distribution } \\
\text { 4.5.: Motorways and Car Parks } \\
\text { 4.6.: Other Services }\end{array}$ \\
\hline $\begin{array}{c}\text { Sector 5: Financial and Real } \\
\text { Estate Services }\end{array}$ & 24 & $\begin{array}{l}\text { 5.1.: Bank } \\
\text { 5.2.: Insurance } \\
\text { 5.3.: Portfolio and Holding } \\
\text { 5.4.: SICAV } \\
\text { 5.5.: Real Estate Agencies and Others }\end{array}$ \\
\hline $\begin{array}{r}\text { Sector 6: Technology and } \\
\text { Telecommunications }\end{array}$ & 8 & $\begin{array}{l}\text { 6.1.: Telecommunications and Others } \\
\text { 6.2.: Electronics and Software }\end{array}$ \\
\hline Total market & 115 & \\
\hline
\end{tabular}


Table 2. Response by sector to inflation announcements taking into account core and 'non-core' inflation rate components

S1, S2..., S6, $\mathbf{M}$ each sector and the total market. In the expressions: $a r_{j}(t)$ is the abnormal returns of sector $j$ in each period $t, \pi^{C}{ }_{t}$ is core inflation, $\pi^{N C}{ }_{t}$ is the 'non-core' component of the inflation rate, and $u_{j t}$ is the error term of sector $j$ (assuming 'myopic expectations'). Sample: Feb. 1995-Dec. 2004 (SUR estimation):

$$
a r_{j}(t)=\alpha_{j}+\beta_{j 1} \cdot \Delta \pi_{t}^{C}+\beta_{j 2} \cdot \Delta \pi_{t}^{N C}+u_{j t}
$$

$t$-statistics in parentheses: ${ }^{\mathrm{a}} \mathrm{p}<0.10,{ }^{\mathrm{b}} \mathrm{p}<0.05,{ }^{\mathrm{c}} \mathrm{p}<0.01$

\begin{tabular}{|c|c|c|c|c|c|c|c|}
\hline Pre-announc. & S1 & S2 & S3 & S4 & S5 & S6 & $\mathbf{M}$ \\
\hline$\Delta \pi_{t}^{C}$ & $\begin{array}{c}0.02 \\
(0.05)\end{array}$ & $\begin{array}{c}0.23 \\
(0.69)\end{array}$ & $\begin{array}{c}0.24 \\
(0.87)\end{array}$ & $\begin{array}{c}0.31 \\
(0.76)\end{array}$ & $\begin{array}{c}0.07 \\
(0.28)\end{array}$ & $\begin{array}{c}0.23 \\
(0.38)\end{array}$ & $\begin{array}{c}0.20 \\
(0.73)\end{array}$ \\
\hline$\Delta \pi^{N C}{ }_{t}$ & $\begin{array}{c}-0.34 \\
(-0.67)\end{array}$ & $\begin{array}{l}-0.96^{\mathrm{a}} \\
(-1.85)\end{array}$ & $\begin{array}{c}-0.51 \\
(-1.18)\end{array}$ & $\begin{array}{c}-0.82 \\
(-1.28)\end{array}$ & $\begin{array}{c}-0.47 \\
(-1.17)\end{array}$ & $\begin{array}{c}-0.61 \\
(-0.64)\end{array}$ & $\begin{array}{c}-0.69 \\
(-1.60)\end{array}$ \\
\hline$R^{2}$ & 0.00 & 0.02 & 0.01 & 0.01 & 0.01 & 0.00 & 0.01 \\
\hline Announc. day & S1 & S2 & S3 & S4 & S5 & S6 & $\mathbf{M}$ \\
\hline$\Delta \pi_{t}^{C}$ & $\begin{array}{c}0.39 \\
(0.82)\end{array}$ & $\begin{array}{c}0.17 \\
(0.42)\end{array}$ & $\begin{array}{c}0.09 \\
(0.26)\end{array}$ & $\begin{array}{c}0.08 \\
(0.15)\end{array}$ & $\begin{array}{c}-0.02 \\
(-0.06)\end{array}$ & $\begin{array}{c}-0.31 \\
(-0.35)\end{array}$ & $\begin{array}{c}0.09 \\
(0.26)\end{array}$ \\
\hline$\Delta \pi^{N C}{ }_{t}$ & $\begin{array}{c}-0.86 \\
(-1.15)\end{array}$ & $\begin{array}{c}-0.29 \\
(-0.46)\end{array}$ & $\begin{array}{c}0.05 \\
(0.10)\end{array}$ & $\begin{array}{c}-0.83 \\
(-1.07)\end{array}$ & $\begin{array}{c}-0.49 \\
(-0.96)\end{array}$ & $\begin{array}{c}-0.43 \\
(-0.31)\end{array}$ & $\begin{array}{c}-0.42 \\
(-0.79)\end{array}$ \\
\hline$R^{2}$ & 0.01 & 0.00 & 0.00 & 0.01 & 0.01 & 0.00 & 0.01 \\
\hline Post-announc. & S1 & S2 & S3 & S4 & S5 & S6 & $\mathbf{M}$ \\
\hline$\Delta \pi_{t}^{C}$ & $\begin{array}{c}0.05 \\
(0.14)\end{array}$ & $\begin{array}{c}-0.09 \\
(-0.28)\end{array}$ & $\begin{array}{c}-0.04 \\
(-0.16)\end{array}$ & $\begin{array}{c}0.13 \\
(0.30)\end{array}$ & $\begin{array}{c}0.02 \\
(0.07)\end{array}$ & $\begin{array}{c}-0.50 \\
(-0.77)\end{array}$ & $\begin{array}{l}-0.06 \\
(-0.22)\end{array}$ \\
\hline$\Delta \pi^{N C}$ & $\begin{array}{l}-1.03^{b} \\
(-1.98)\end{array}$ & $\begin{array}{l}-1.03^{b} \\
(-2.04)\end{array}$ & $\begin{array}{c}-0.67 \\
(-1.58)\end{array}$ & $\begin{array}{l}-1.06 \\
(-1.55)\end{array}$ & $\begin{array}{c}-0.55 \\
(-1.37)\end{array}$ & $\begin{array}{c}-0.09 \\
(-0.09)\end{array}$ & $\begin{array}{l}-0.76^{\mathrm{a}} \\
(-1.74)\end{array}$ \\
\hline$R^{2}$ & 0.02 & 0.03 & 0.02 & 0.01 & 0.01 & 0.00 & 0.02 \\
\hline
\end{tabular}


Table 3. Response by sector to inflation announcements taking into account core and 'non-core' inflation rate components and the spread between Spanish and European HICP, according to the direction of the news and the state of the economy

S1, S2..., S6, $M$ each sector and the total market. In the expressions: $a_{j}(t)$ represents the abnormal returns of sector $j$ in each period $t, \pi^{C}{ }_{t}$ is core inflation, $\pi^{N C}{ }_{t}$ is the 'non-core' component of the inflation rate, spread ${ }_{t}$ represents the spread between Spanish and European inflation, both harmonized (orthogonalized), and $u_{j t}$ is the error term of sector $j$. Dummy variables distinguish between positive $(+)$ and negative $(-)$ inflation spreads and between a high $(H)$ and non-high (NH) state of economic activity. Sample: Feb. 1995-Dec. 2004 (SUR estimation): $\operatorname{ar}_{j}(t)=\alpha_{j}+\beta_{j 1} \cdot \Delta \pi_{t}^{C}+\beta_{j 2} \cdot \Delta \pi_{t}^{N C}+\beta_{j 3} \cdot D_{H}^{+} \cdot \mid \Delta$ spread $_{t}\left|+\beta_{j 4} \cdot D_{N H}^{+} \cdot\right| \Delta$ spread $_{t}\left|+\beta_{j 5} \cdot D_{H}^{-} \cdot\right| \Delta$ spread $_{t}\left|+\beta_{j 6} \cdot D_{N H}^{-} \cdot\right| \Delta$ spread $_{t} \mid+u_{j t}$ \# Test of equality between inflation coefficients in different scenarios. $t$-statistics in parentheses: ${ }^{\mathrm{a}} \mathrm{p}<0.10,{ }^{\mathrm{b}} \mathrm{p}<0.05,{ }^{\mathrm{c}} \mathrm{p}<0.01$

\begin{tabular}{|c|c|c|c|c|c|c|c|}
\hline Pre-announc. & S1 & $\mathbf{S 2}$ & S3 & S4 & S5 & S6 & $\mathbf{M}$ \\
\hline$\Delta \pi_{t}^{C}$ & $\begin{array}{c}0.25 \\
(0.73) \\
\end{array}$ & $\begin{array}{c}0.29 \\
(0.83) \\
\end{array}$ & $\begin{array}{c}0.40 \\
(1.35) \\
\end{array}$ & $\begin{array}{c}0.32 \\
(0.74) \\
\end{array}$ & $\begin{array}{c}0.26 \\
(0.95) \\
\end{array}$ & $\begin{array}{c}0.56 \\
(0.87) \\
\end{array}$ & $\begin{array}{c}0.34 \\
(1.17) \\
\end{array}$ \\
\hline$\Delta \pi^{N C}{ }_{t}$ & $\begin{array}{c}-0.68 \\
(-1.31) \\
\end{array}$ & $\begin{array}{l}-1.04^{\mathrm{a}} \\
(-1.92) \\
\end{array}$ & $\begin{array}{c}-0.69 \\
(-1.52) \\
\end{array}$ & $\begin{array}{c}-0.85 \\
(-1.28) \\
\end{array}$ & $\begin{array}{l}-0.70^{a} \\
(-1.70) \\
\end{array}$ & $\begin{array}{c}-1.00 \\
(-1.02) \\
\end{array}$ & $\begin{array}{l}-0.86^{\mathrm{a}} \\
(-1.94) \\
\end{array}$ \\
\hline $\begin{array}{c}+, \boldsymbol{H} \\
\text { sspread }_{t}\end{array}$ & $\begin{array}{c}0.81 \\
(0.55) \\
\end{array}$ & $\begin{array}{c}-0.94 \\
(-0.62) \\
\end{array}$ & $\begin{array}{c}-0.56 \\
(-0.44) \\
\end{array}$ & $\begin{array}{c}0.78 \\
(0.42) \\
\end{array}$ & $\begin{array}{c}-0.61 \\
(-0.53) \\
\end{array}$ & $\begin{array}{r}-1.39 \\
(-0.50) \\
\end{array}$ & $\begin{array}{r}-0.37 \\
(-0.30) \\
\end{array}$ \\
\hline $\begin{array}{c}+, \mathrm{NH} \\
\text { sppread }_{t}\end{array}$ & $\begin{array}{l}1.43^{b} \\
(2.20) \\
\end{array}$ & $\begin{array}{c}0.35 \\
(0.52) \\
\end{array}$ & $\begin{array}{l}1.06^{\mathrm{a}} \\
(1.88) \\
\end{array}$ & $\begin{array}{c}0.73 \\
(0.88) \\
\end{array}$ & $\begin{array}{l}1.12^{b} \\
(2.16) \\
\end{array}$ & $\begin{array}{c}1.67 \\
(1.35) \\
\end{array}$ & $\begin{array}{l}0.97^{\mathrm{a}} \\
(1.73) \\
\end{array}$ \\
\hline $\begin{array}{c}-, \boldsymbol{H} \\
\text { sspread }_{t}\end{array}$ & $\begin{array}{c}0.80 \\
(1.00) \\
\end{array}$ & $\begin{array}{c}0.29 \\
(0.35) \\
\end{array}$ & $\begin{array}{c}-0.09 \\
(-0.13) \\
\end{array}$ & $\begin{array}{c}-0.60 \\
(-0.58) \\
\end{array}$ & $\begin{array}{c}0.41 \\
(0.65) \\
\end{array}$ & $\begin{array}{c}0.81 \\
(0.53) \\
\end{array}$ & $\begin{array}{r}0.16 \\
(0.23) \\
\end{array}$ \\
\hline $\begin{array}{c}-, \text { NH } \\
\text { sspread }_{t}\end{array}$ & $\begin{array}{c}0.69 \\
(1.10) \\
\end{array}$ & $\begin{array}{c}-0.00 \\
(-0.00) \\
\end{array}$ & $\begin{array}{r}0.30 \\
(0.54) \\
\end{array}$ & $\begin{array}{c}-0.33 \\
(-0.41) \\
\end{array}$ & $\begin{array}{c}0.38 \\
(0.77) \\
\end{array}$ & $\begin{array}{c}0.95 \\
(0.80) \\
\end{array}$ & $\begin{array}{r}0.23 \\
(0.44) \\
\end{array}$ \\
\hline$R^{2}$ & 0.03 & 0.02 & 0.02 & 0.01 & 0.02 & 0.01 & 0.02 \\
\hline Wald \# & 6.38 & 3.43 & 5.62 & 3.12 & 7.09 & 3.10 & 5.74 \\
\hline Announc. day & S1 & S2 & S3 & S4 & S5 & S6 & $\mathbf{M}$ \\
\hline$\Delta \pi^{C}{ }_{t}$ & $\begin{array}{c}0.55 \\
(1.10)\end{array}$ & $\begin{array}{c}0.35 \\
(0.82)\end{array}$ & $\begin{array}{c}0.35 \\
(0.98)\end{array}$ & $\begin{array}{c}0.24 \\
(0.47)\end{array}$ & $\begin{array}{c}0.10 \\
(0.29)\end{array}$ & $\begin{array}{c}0.36 \\
(0.39)\end{array}$ & $\begin{array}{c}0.30 \\
(0.86)\end{array}$ \\
\hline$\Delta \pi^{N C}{ }_{t}$ & $\begin{array}{r}-0.89 \\
(-1.17) \\
\end{array}$ & $\begin{array}{c}-0.42 \\
(-0.64) \\
\end{array}$ & $\begin{array}{c}-0.11 \\
(-0.20) \\
\end{array}$ & $\begin{array}{c}-1.02 \\
(-1.30) \\
\end{array}$ & $\begin{array}{c}-0.67 \\
(-1.29) \\
\end{array}$ & $\begin{array}{c}-1.16 \\
(-0.82) \\
\end{array}$ & $\begin{array}{c}-0.61 \\
(-1.13) \\
\end{array}$ \\
\hline $\begin{array}{c}+, H \\
\text { sspread }_{t}\end{array}$ & $\begin{array}{l}-1.25 \\
(-0.59) \\
\end{array}$ & $\begin{array}{c}1.50 \\
(0.82) \\
\end{array}$ & $\begin{array}{l}-2.60^{a} \\
(-1.71) \\
\end{array}$ & $\begin{array}{c}2.81 \\
(1.27) \\
\end{array}$ & $\begin{array}{c}2.09 \\
(1.42) \\
\end{array}$ & $\begin{array}{c}-0.51 \\
(-0.13) \\
\end{array}$ & $\begin{array}{c}0.47 \\
(0.31) \\
\end{array}$ \\
\hline $\begin{array}{c}+, \mathrm{NH} \\
\text { sspread }_{t}\end{array}$ & $\begin{array}{c}-0.58 \\
(-0.61) \\
\end{array}$ & $\begin{array}{c}0.26 \\
(0.32) \\
\end{array}$ & $\begin{array}{l}1.24^{\mathrm{a}} \\
(1.83) \\
\end{array}$ & $\begin{array}{c}-0.26 \\
(-0.26) \\
\end{array}$ & $\begin{array}{c}0.59 \\
(0.90) \\
\end{array}$ & $\begin{array}{c}2.29 \\
(1.29) \\
\end{array}$ & $\begin{array}{c}0.61 \\
(0.91) \\
\end{array}$ \\
\hline $\begin{array}{c}-, \boldsymbol{H} \\
\Delta \text { spread }_{t}\end{array}$ & $\begin{array}{c}-0.28 \\
(-0.24) \\
\end{array}$ & $\begin{array}{c}-0.77 \\
(-0.77) \\
\end{array}$ & $\begin{array}{r}-1.08 \\
(-1.29) \\
\end{array}$ & $\begin{array}{c}0.58 \\
(0.48) \\
\end{array}$ & $\begin{array}{c}0.25 \\
(0.31) \\
\end{array}$ & $\begin{array}{r}1.18 \\
(0.54) \\
\end{array}$ & $\begin{array}{r}-0.27 \\
(-0.33) \\
\end{array}$ \\
\hline $\begin{array}{c}-, N H \\
\text { sspread }_{t}\end{array}$ & $\begin{array}{l}1.73^{\mathrm{a}} \\
(1.89)\end{array}$ & $\begin{array}{l}1.78^{b} \\
(2.27)\end{array}$ & $\begin{array}{c}0.91 \\
(1.39) \\
\end{array}$ & $\begin{array}{l}2.06^{b} \\
(2.16)\end{array}$ & $\begin{array}{c}0.83 \\
(1.31) \\
\end{array}$ & $\begin{array}{l}3.46^{\mathrm{b}} \\
(2.03)\end{array}$ & $\begin{array}{l}1.47^{b} \\
(2.28) \\
\end{array}$ \\
\hline$R^{2}$ & 0.05 & 0.06 & 0.08 & 0.06 & 0.04 & 0.05 & 0.05 \\
\hline Wald & 6.44 & 6.71 & $10.40^{\mathrm{a}}$ & 7.81 & 5.04 & 5.64 & 6.54 \\
\hline Post-announc. & S1 & S2 & S3 & S4 & S5 & S6 & $\mathbf{M}$ \\
\hline$\Delta \boldsymbol{\pi}_{t}^{C}$ & $\begin{array}{c}0.13 \\
(0.36) \\
\end{array}$ & $\begin{array}{c}-0.05 \\
(-0.15) \\
\end{array}$ & $\begin{array}{c}-0.06 \\
(-0.21) \\
\end{array}$ & $\begin{array}{c}0.36 \\
(0.78) \\
\end{array}$ & $\begin{array}{c}0.04 \\
(0.13) \\
\end{array}$ & $\begin{array}{c}-0.47 \\
(-0.69) \\
\end{array}$ & $\begin{array}{c}-0.02 \\
(-0.05) \\
\end{array}$ \\
\hline$\Delta \pi^{N C}{ }_{t}$ & $\begin{array}{l}-1.05^{b} \\
(-1.96) \\
\end{array}$ & $\begin{array}{l}-1.06^{b} \\
(-2.01) \\
\end{array}$ & $\begin{array}{c}-0.61 \\
(-1.38) \\
\end{array}$ & $\begin{array}{l}-1.36^{\mathrm{a}} \\
(-1.91) \\
\end{array}$ & $\begin{array}{c}-0.52 \\
(-1.24) \\
\end{array}$ & $\begin{array}{c}-0.21 \\
(-0.20) \\
\end{array}$ & $\begin{array}{l}-0.78^{a} \\
(-1.73) \\
\end{array}$ \\
\hline $\begin{array}{c}+, \boldsymbol{H} \\
\text { sspread }_{t}\end{array}$ & $\begin{array}{c}1.37 \\
(0.91)\end{array}$ & $\begin{array}{c}-0.10 \\
(-0.07)\end{array}$ & $\begin{array}{c}0.16 \\
(0.13)\end{array}$ & $\begin{array}{c}-0.31 \\
(-0.16)\end{array}$ & $\begin{array}{c}-0.49 \\
(-0.42)\end{array}$ & $\begin{array}{c}0.39 \\
(0.13)\end{array}$ & $\begin{array}{c}-0.08 \\
(-0.06)\end{array}$ \\
\hline $\begin{array}{c}+, \mathrm{NH} \\
\text { sspread }_{t}\end{array}$ & $\begin{array}{c}0.51 \\
(0.76)\end{array}$ & $\begin{array}{c}-0.07 \\
(-0.11)\end{array}$ & $\begin{array}{c}-0.35 \\
(-0.63)\end{array}$ & $\begin{array}{c}0.82 \\
(0.92)\end{array}$ & $\begin{array}{c}-0.02 \\
(-0.04)\end{array}$ & $\begin{array}{c}-0.55 \\
(-0.42)\end{array}$ & $\begin{array}{c}0.01 \\
(0.02)\end{array}$ \\
\hline $\begin{array}{c}-, H \\
\text { sspread }_{t}\end{array}$ & $\begin{array}{l}-1.41^{a} \\
(-1.72) \\
\end{array}$ & $\begin{array}{c}0.09 \\
(0.11) \\
\end{array}$ & $\begin{array}{c}-0.33 \\
(-0.49) \\
\end{array}$ & $\begin{array}{c}1.02 \\
(0.94) \\
\end{array}$ & $\begin{array}{c}-0.50 \\
(-0.78) \\
\end{array}$ & $\begin{array}{c}1.89 \\
(1.18) \\
\end{array}$ & $\begin{array}{c}-0.11 \\
(-0.16) \\
\end{array}$ \\
\hline $\begin{array}{c}-, \mathrm{NH} \\
\Delta \text { spread }_{t}\end{array}$ & $\begin{array}{c}0.77 \\
(1.20)\end{array}$ & $\begin{array}{c}0.39 \\
(0.61)\end{array}$ & $\begin{array}{c}0.25 \\
(0.48)\end{array}$ & $\begin{array}{c}0.98 \\
(1.14)\end{array}$ & $\begin{array}{c}0.19 \\
(0.38)\end{array}$ & $\begin{array}{c}0.39 \\
(0.31)\end{array}$ & $\begin{array}{c}0.41 \\
(0.75)\end{array}$ \\
\hline$R^{2}$ & 0.05 & 0.03 & 0.02 & 0.02 & 0.01 & 0.01 & 0.02 \\
\hline Wald & 8.94 & 2.82 & 1.81 & 4.95 & 1.71 & 2.36 & 2.48 \\
\hline
\end{tabular}


Table 4. Long-term response by sector

S1, S2..., S6, $\mathbf{M}$ each sector and the total market. In the expressions: $r_{j t}$ is the monthly stock return of sector $j$ in period $t, \pi^{C}{ }_{t}$ is core inflation, $\pi^{N C}{ }_{t}$ is the 'non-core' component of the inflation rate, spread $_{t}$ represents the spread between Spanish and European inflation, both harmonized (orthogonalized), and $u_{j t}$ is the error term of sector $j$. Sample: Feb. 1993-Dec. 2004 (SUR estimation):

$$
r_{j t}=\alpha_{j}+\beta_{j 1} \cdot \Delta \pi_{t}^{C}+\beta_{j 2} \cdot \Delta \pi_{t}^{N C}+\beta_{j 3} \cdot \Delta \text { spread }_{t}+\beta_{j 4} \cdot \Delta \pi_{t-1}^{C}+\beta_{j 5} \cdot \Delta \pi_{t-1}^{N C}+\beta_{j 6} \cdot \Delta \text { spread }_{t-1}+u_{j t}
$$

$t$-statistics in parentheses: ${ }^{\mathrm{a}} \mathrm{p}<0.10,{ }^{\mathrm{b}} \mathrm{p}<0.05,{ }^{\mathrm{c}} \mathrm{p}<0.01$

\begin{tabular}{|c|c|c|c|c|c|c|c|}
\hline & S1 & S2 & S3 & S4 & S5 & S6 & $\mathbf{M}$ \\
\hline$\Delta \pi_{t}^{C}$ & $\begin{array}{c}2.25 \\
(0.68)\end{array}$ & $\begin{array}{c}-0.56 \\
(-0.14)\end{array}$ & $\begin{array}{c}0.35 \\
(0.09)\end{array}$ & $\begin{array}{c}2.35 \\
(0.59)\end{array}$ & $\begin{array}{c}1.42 \\
(0.52)\end{array}$ & $\begin{array}{c}-3.59 \\
(-0.56)\end{array}$ & $\begin{array}{c}0.70 \\
(0.22)\end{array}$ \\
\hline$\Delta \pi^{N C}{ }_{t}$ & $\begin{array}{c}-1.71 \\
(-0.75)\end{array}$ & $\begin{array}{l}-5.28^{a} \\
(-1.95)\end{array}$ & $\begin{array}{c}-2.50 \\
(-0.97)\end{array}$ & $\begin{array}{c}-3.59 \\
(-1.30)\end{array}$ & $\begin{array}{c}-2.35 \\
(-1.24)\end{array}$ & $\begin{array}{c}-5.52 \\
(-1.25)\end{array}$ & $\begin{array}{l}-3.38 \\
(-1.51)\end{array}$ \\
\hline$\Delta_{\text {spread }}$ & $\begin{array}{c}-0.23 \\
(-0.10)\end{array}$ & $\begin{array}{c}-1.43 \\
(-0.50)\end{array}$ & $\begin{array}{c}1.53 \\
(0.56)\end{array}$ & $\begin{array}{c}1.63 \\
(0.55)\end{array}$ & $\begin{array}{c}0.48 \\
(0.24)\end{array}$ & $\begin{array}{c}2.69 \\
(0.58)\end{array}$ & $\begin{array}{c}0.19 \\
(0.08)\end{array}$ \\
\hline$\Delta \pi_{t-1}^{C}$ & $\begin{array}{l}-7.57^{\mathrm{b}} \\
(-2.47) \\
\end{array}$ & $\begin{array}{l}-9.36^{c} \\
(-2.59) \\
\end{array}$ & $\begin{array}{c}-5.61 \\
(-1.64) \\
\end{array}$ & $\begin{array}{l}-7.45^{b} \\
(-2.01) \\
\end{array}$ & $\begin{array}{l}-4.97^{a} \\
(-1.96) \\
\end{array}$ & $\begin{array}{l}-10.24^{\mathrm{a}} \\
(-1.74)\end{array}$ & $\begin{array}{l}-7.25^{b} \\
(-2.42)\end{array}$ \\
\hline$\Delta \pi_{t-1}^{N C}$ & $\begin{array}{c}-0.98 \\
(-0.42) \\
\end{array}$ & $\begin{array}{c}-0.13 \\
(-0.05) \\
\end{array}$ & $\begin{array}{c}0.89 \\
(0.34) \\
\end{array}$ & $\begin{array}{c}-2.22 \\
(-0.78) \\
\end{array}$ & $\begin{array}{c}-1.44 \\
(-0.74) \\
\end{array}$ & $\begin{array}{c}-1.61 \\
(-0.36) \\
\end{array}$ & $\begin{array}{c}-1.11 \\
(-0.48) \\
\end{array}$ \\
\hline$\Delta_{\text {spread }} t-1$ & $\begin{array}{c}-1.01 \\
(-0.41)\end{array}$ & $\begin{array}{c}-3.55 \\
(-1.23)\end{array}$ & $\begin{array}{c}-0.42 \\
(-0.16)\end{array}$ & $\begin{array}{c}-0.78 \\
(-0.26)\end{array}$ & $\begin{array}{c}-0.23 \\
(-0.11)\end{array}$ & $\begin{array}{c}0.56 \\
(0.12)\end{array}$ & $\begin{array}{c}-0.96 \\
(-0.41)\end{array}$ \\
\hline Adj. $R^{2}$ & 0.00 & 0.04 & -0.01 & 0.00 & 0.00 & -0.01 & 0.01 \\
\hline
\end{tabular}


Figure 1. Evolution of the total inflation rate and its two components, core and "non-core" inflation

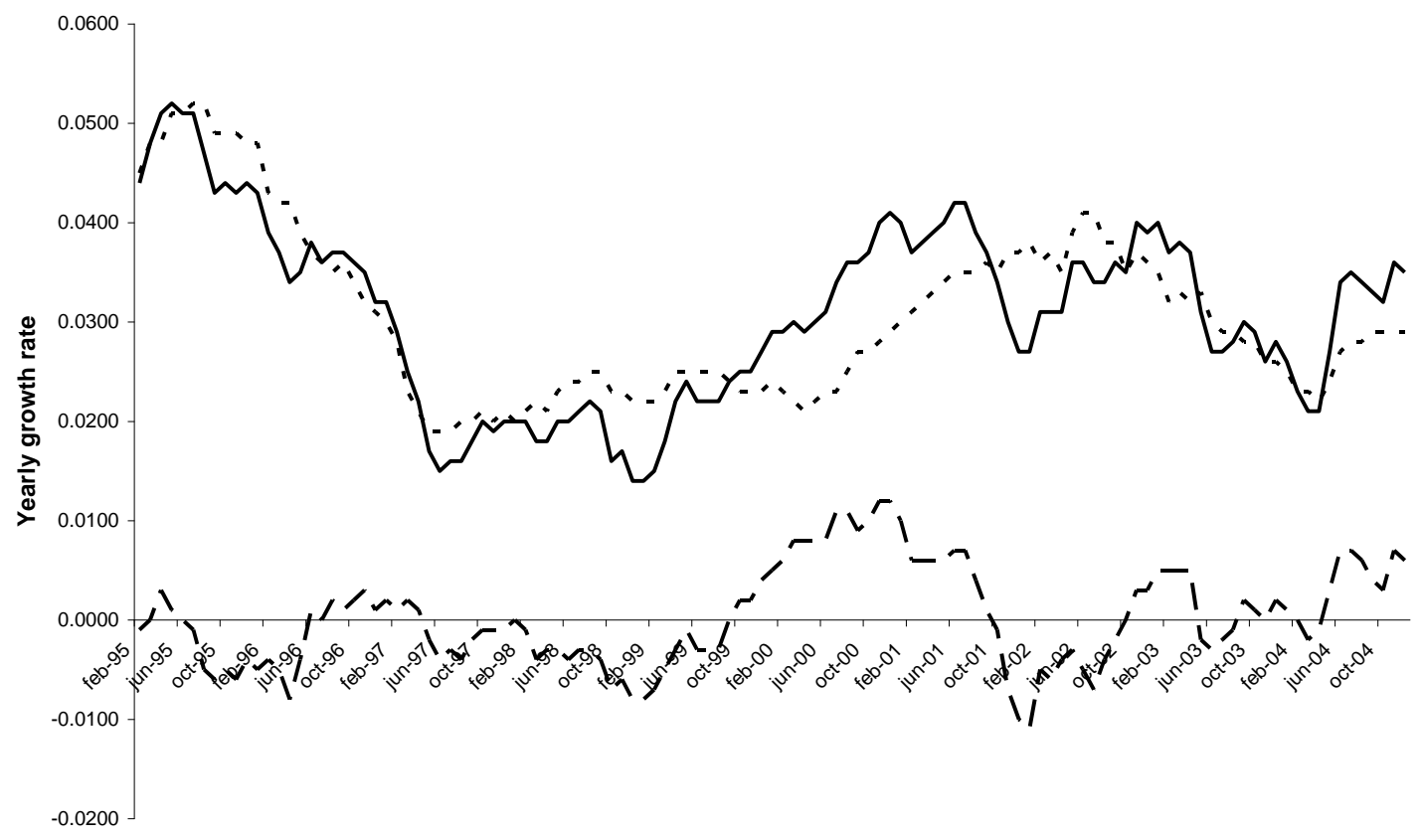

Figure 2. Evolution of the inflation rate changes and its core and "non-core" components

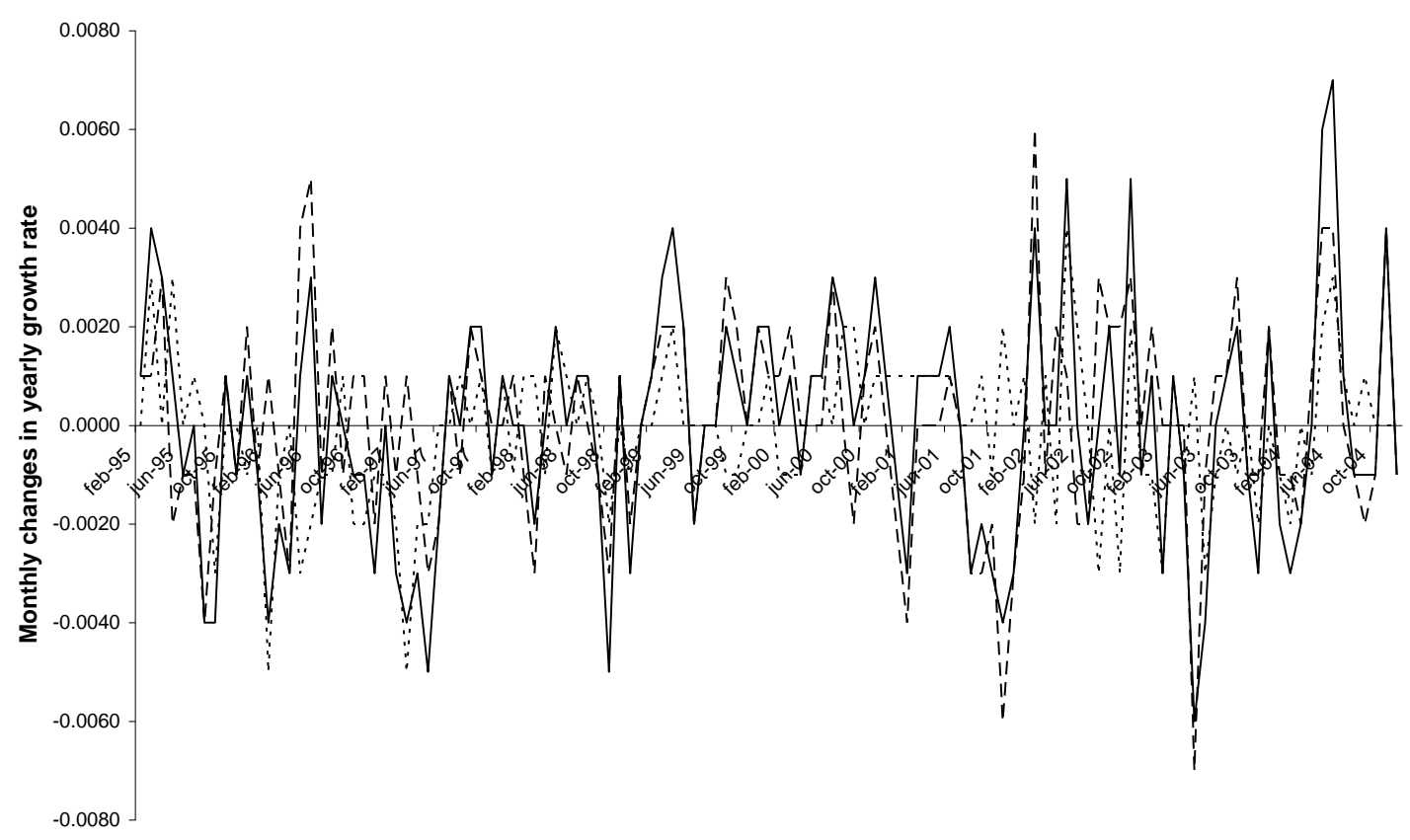


Figure 3. Evolution of Spanish and European harmonized inflation rates and the spread between them

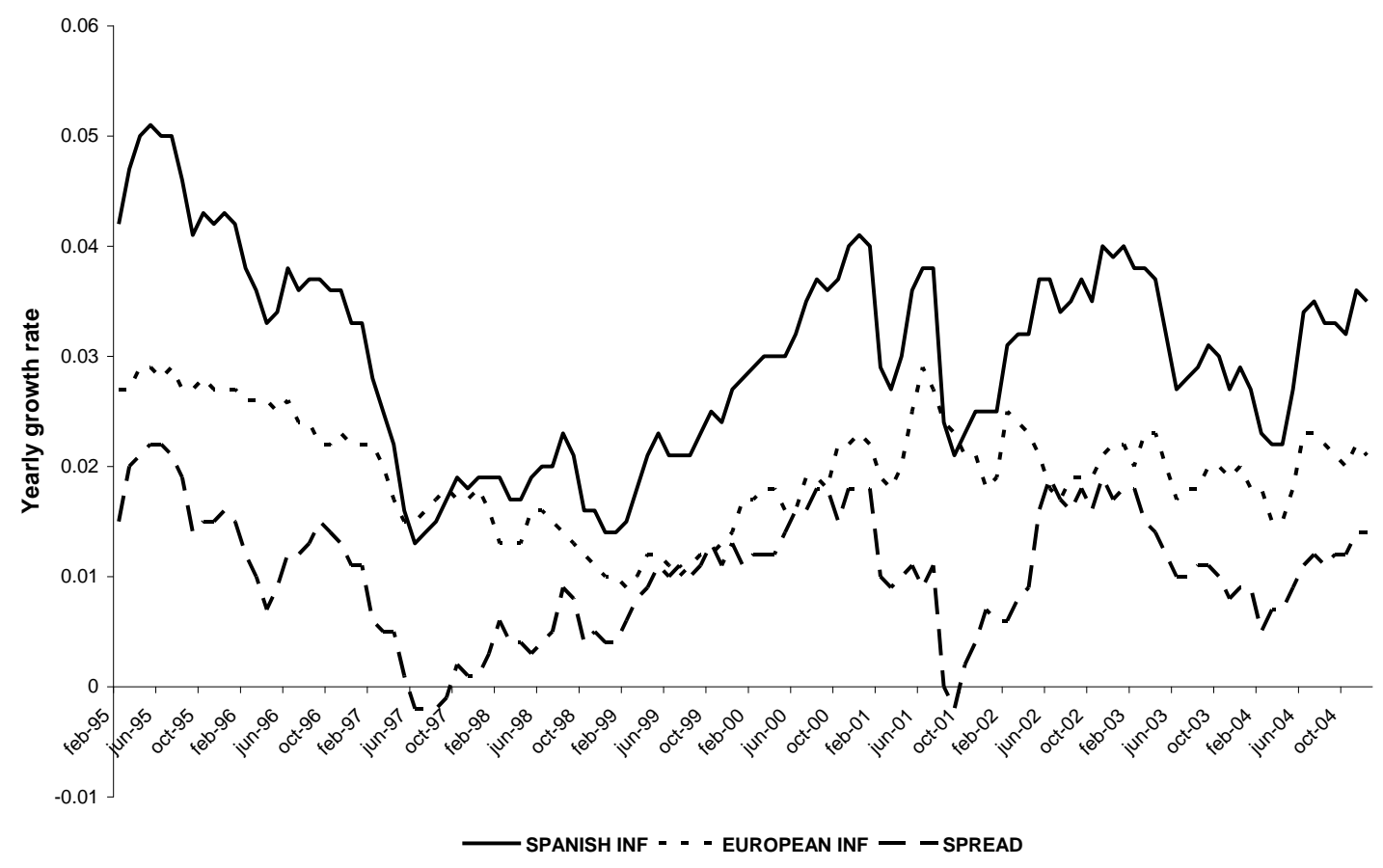

Figure 4. Evolution of changes in the spread between Spanish and Euro Area harmonized inflation rates

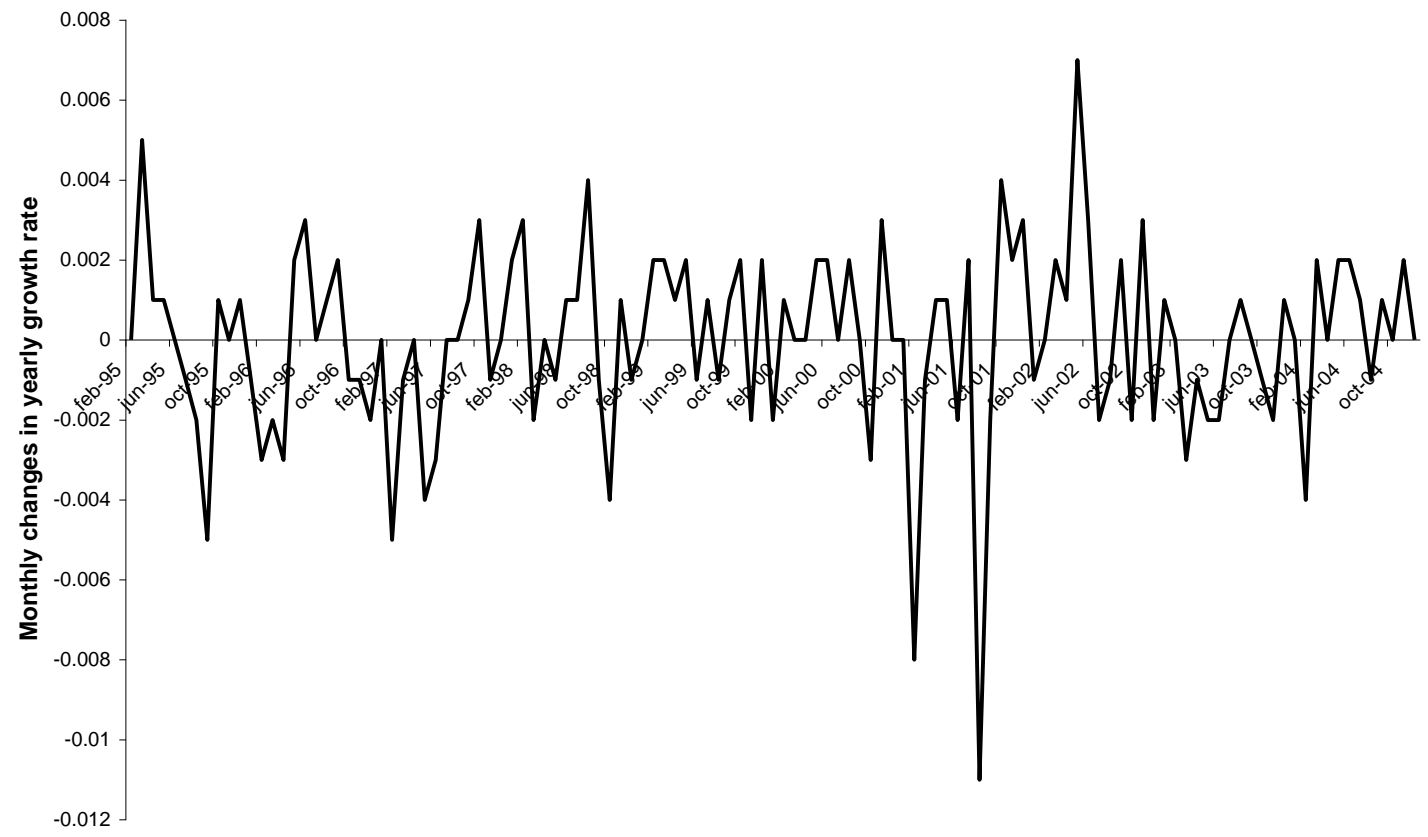

- SPREAD CHANGES 